\title{
infectio
}

\section{Hospitalization costs due to severe acute respiratory infection (SARI) in three Central American countries}

\author{
Nelson Alvis-Guzmán ${ }^{1,2, *}$, Carlos Marín-Correa', Carlos Andrés Castañeda-Orjuela ${ }^{1,3}$, Carolina Sánchez-Ruiz', \\ María Carrasquilla-Sotomayor ${ }^{1,2}$, Felix Sanchez-Largaespada ${ }^{4}$, Ricardo Mena ${ }^{5}$, Homer Mejía ${ }^{6}$
}

\begin{abstract}
Objective: To estimate the direct medical costs of severe acute respiratory infection (SARI) in children and adults from three Central American countries with a bottom-up costing approach.

Methods: The costs of inpatients treatment were estimated through the retrospective bottom-up costing in a randomized sample of clinical records from SARI patients treated in teaching tertiary hospitals during 2009 - 2011 period. Activities incurred per patient were registered and a setting-specific cost per activity was acquired. Average cost per patient in the group of children and elderly adults was estimated for each country. In Nicaragua, only the pediatric population was included. Costs were expressed in local currency (2011), American dollars, and international dollars (2005) for country comparison.

Results: The care cost per case in children in Guatemala was the cheaper $(\$ \$ 971.95)$ compared to Nicaragua $(I \$ 1,431.96)$ and Honduras $(I \$ 1,761.29)$. In adults, the treatment cost for Guatemala was the more expensive: $\$ \$ 4,065.00$ vs. $\$ 2,707.91$ in Honduras.

Conclusion: Bottom-up costing of SARI cases allowed the mean estimates per treated case that could have external validity for the target population diagnosed in hospitals with similar epidemiological profiles and level of complexity for the study countries. This information is very relevant for the decision-making.
\end{abstract}

Key words: Cost and cost Analysis, Severe Acute Respiratory Infection, Guatemala, Honduras, Nicaragua

\section{Costos de hospitalización de infección respiratoria aguda grave (IRAG) en tres países de América Central}

\section{Resumen}

Objetivo: Estimar los costos directos de la atención de infección respiratoria aguda (IRAG) en niños y adultos en tres países de América Central. Métodos: Los costos de pacientes hospitalizados fueron estimados a través de análisis retrospectivo en una muestra aleatoria de registros de historias clínicas de casos de IRAG tratado en hospitales universitarios durante el periodo 2009-2011. Las actividades incurridas por paciente fueron registradas y un costo especifico para cada sitio fue estimado. El costo por cada niño y adulto mayor fue estimado para cada país. En Nicaragua sólo se incluyó población pediátrica. Los costos fueron expresados en moneda local (2011), dolar americano y dolar internacional (2005).

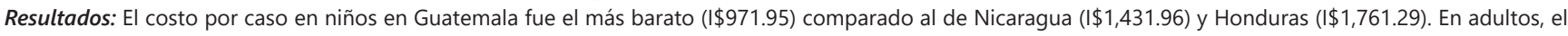
costo de tratamiento para Guatemala fue el más costoso: $1 \$ 4,065.00$ vs. $1 \$ 2,707.91$ en Honduras.

Conclusión: Los costos de tratar casos IRAG estimados a partir de costos promedios pro caso pueden tener validez externa para hospitales con perfiles epidemiologicos similares y nivel de complejidad de atención para los países del estudio. Esta información es muy relevante para la toma de decisiones.

Palabras claves: Análisis de costo beneficio, Infección Respiratoria Aguda, Guatemala, Honduras, Nicaragua

1 Cost Project, Cooperative Agreement-The Task Force TEPHINET CDC

2 Grupo de Investigación en Economía de la Salud, Universidad de Cartagena, Cartagena, Colombia

3 Epidemiology and Public Health Evaluation Group. Facultad de Medicina. Universidad Nacional de Colombia, Bogotá, Colombia

4 Jefe del departamento de Medicina y Post Grado, Hospital Infantil Manuel de Jesús Rivera, Managua, Nicaragua

5 Jefe de Epidemiologia, Hospital General San Juan de Dios, Guatemala, Guatemala

6 Dirección General de Vigilancia de la Salud, Honduras

* Autor para correspondencia.

Correo electrónico: nalvis@yahoo.com
Recibido: 21/07/2017; Recibido en forma revisada: 28/11/2017; Aceptado: 11/01/2018

Cómo citar este artículo: N. Alvis-Guzmán, et al. Hospitalization costs due to severe acute respiratory infection (SARI) in three Central American countries. Infectio 2018; 22(3): 159-166 


\section{Introduction}

Acute respiratory infection (ARI) is one of the main causes of infant morbidity and mortality in children under 5 years of age in developing countries ${ }^{1,2}$. Severe Acute Respiratory Infection (SARI) has been the main cause of death in children during the last decades ${ }^{2}$. During the $80 \mathrm{~s}$, it was estimated that, globally, SARI was the main cause for the death of 4 million people per year, 2.6 million deaths in children under one year of age and 1.4 million deaths in children between 1 and 4 years of age $^{3}$. Influenza has a worldwide distribution, with an estimated annual attack rate of $5-10 \%$ in adults, and $20-30 \%$ in children. The epidemic outbreak mainly takes place during the rainy season in mild climates and it is less predictable in tropical regions ${ }^{4}$. The highest infection rates are observed in children from 5 to 9 years of age, but the most severe morbidity and mortality due to influenza mainly affect children under 2 years of age, elderly, and people with high risk factors, like lung or heart diseases, diabetes mellitus, kidney failure and other types of immunodeficiencies ${ }^{4}$.

In developing countries, given the strength and development of the information systems, epidemiological surveillance may only predict the impact of influenza epidemics with some certainty. However, one of the most important limitations for the introduction of public health measures against influenza in developing countries is related to the lack of data, in part due to the weak surveillance systems and the characteristics of the virus, given that it is difficult to define its seasonality in tropical and subtropical countries where the patterns of viral circulation are unstable ${ }^{5,6}$. Data of studies carried out in tropical countries ${ }^{7,8}$, as well as in Central America ${ }^{9-11}$, have shown that SARI caused by influenza constitutes an important proportion of the cases and causes of the disease assisted by the health system.

Additionally, influenza generates a considerable economic burden regarding health care expenses ${ }^{12}$ and loss of work and/or school days. In a recent review about absenteeism in influenza patients, the average loss of days was of $5.9 \pm 4.7^{13}$. Similarly, recent estimates in the United States, based on the population of 2003, indicated that annually, the influenza outbreak generates an average of 610,660 years of loss of life (YLL), 3.1 million hospitalization days, and 31.4 million medical consultations. Direct annual average care costs are of U\$10.4 billion (C195\% U\$4.1 - U\$22.2) and the total annual economic burden of the influenza epidemic is estimated in U\$87.1 billion (C195\%: U\$47.2 - U\$149.5) (12). In Latin American and the Caribbean Region SARI costs studies are not available, and the estimation from WHO-CHOICE is not SARIspecific. The aim of this study was to estimate hospitalization costs of SARI in three Central American countries, using the bottom-up approach.

\section{Methods}

The present analysis estimates the treatment costs per patient hospitalized in tertiary hospitals due to SARI-associated influenza in three countries in Central America, from a retrospective bottom-up costing analysis of a random sample with cases that occurred between 2009 and 2011. The perspective of the study was the hospital. Out-of-pocket and indirect costs, such as loss of productivity by patient and their caregivers, were excluded.

Countries and hospitals: This study was carried out in Guatemala, Honduras, and Nicaragua. National reference hospitals were chosen, those in which high complexity cases are treated and have an important population influence area, prioritizing the hospital-schools. Hospitalized SARI costs were evaluated at the Hospital General San Juan de Dios in Guatemala city (in populations of 6-month-old to 9-year-old children and elderly over 65 years of age); in Honduras, at the Hospital Mario Catarino Rivas in San Pedro Sula (6-monthold to under 3 years of age children and adults over 60 years of age); and in Nicaragua, at the Hospital Infantil Manuel de Jesús Rivera in Managua (6-month-old to under 9 years of age children).

Period of study and diagnoses included: The target population was identified in a randomly retrospective sample during the 2009-2011 period, which included all those patients hospitalized due to any of the corresponding SARI related ICD10 discharge diagnosis codes: J050, J051, J100, J101, J108, J110, J111, J118, J120, J121, J122, J128, J129, J13, J14, J150J159, J180, J181, J188, J189, J200- J209, J210, J218, J219, J22, J80, J960, J961, and $J 969$ in the age group defined for the included hospital.

Random sample size calculation and selection: Population universes were defined at each hospital based on all the discharges during the period, and the corresponding ICD10 codes. The sample size formula for estimating an average was used to reach a $95 \%$ confidence level and a relative error margin of $10 \%$. An average cost per case of US\$1,020 was considered as an a priori parameter, and a standard deviation of US\$481 for the hospitalization due to pneumonia had been reported in selected studies from the literature. The same parameters were used for the adult and infant population groups, because the available information only corresponded to that age group. The calculated sample sizes were adjusted regarding the universe size for finite populations and a withdrawal rate of $20 \%$.

To obtain statistical significance in the estimation of the average cost 101 children and 90 adults in Guatemala, 97 children and 55 adults in Honduras, and 102 children in $\mathrm{Ni}$ caragua were required. A randomized sampling was carried out among all the clinical registries identified with diagnoses of interest, with the following criteria: 1) discharge diagnosis due to SARI, and 2) patients of both genders with ages into 
the selected range. The following were excluded: 1) diagnosis of nosocomial pneumonia; 2) incomplete clinical records; 3) patients with voluntary discharge; 4) hospitalizations due to this event in another institution (referred); or 5) length of hospital stay less than 72 hours.

\section{Data Collection}

\section{Information about usage frequency per patient}

A survey form was designed, requesting identification data of the patient, diagnosis, clinical variables, and pathological background. Based on the clinical record, the collecting tool allowed registering all the cost-generating activities applied to the patients during their stay; these were classified according to five categories: costs of administrative and use of space, assistance by medical staff, lab tests and radiology, procedures, and drugs.

\section{Estimation of the administrative costs and unit costs per activity}

Using semi-structured interviews and databases review at the hospital's financial department, all available information about costs was collected for every activity related to hospitalization. Regarding administrative costs, recurring costs (salaries and supplies), and capital costs (buildings and equipment) were included. Each identified costs was assigned to a category within a general classification (staff, equipment, supplies and buildings), and the most suitable adjustment method to estimate the cost associated to hospital stay was identified. The estimated costs were divided into:

Administrative costs: Staff costs (at management level and general services, like cleaning and security), adjusted by the hospital's production level. Estimation was based on the occupied bed/day (OBD). The costs were compared with the costs estimated by the WHO's CHOICE initiative for each of the three countries.

General capital costs: included building and equipment with a lifespan of more than one year. When they are of shared use, require prorating by the institution's production level. For the annual estimation of the capital costs we used the 'annualization' process to calculate the economic costs, assuming an annual discount rate of $3 \%$ and an average lifespan of 20 years for buildings and 5 for equipment.

Costs of capital goods: They included equipment for exclusive use of the patients' evaluation. This equipment corresponded to that found at the services where the patients of this study were hospitalized (adult medicine, pediatric medicine or intensive care units); these costs were also annualized.

Costs of the medical staff: They included the costs of staff that worked directly with the patient (physicians, nurses, and therapists). The cost was based on the estimation of cost per unit of service and the registered number of consultations per patient in data collection. From the monthly average salaries per position, we assumed a productivity level to estimate the consultation cost: 8 hours of daily work, 20 days in the month, and 20 minutes per consultation for general practitioner or therapists, 30 minutes for a specialist or resident, and 40 minutes for a psychologist or social worker.

Lab costs: In Guatemala, a total lab cost (recurrent and capital costs) in the clinical lab service was estimated, given the level of production for each number of lab tests and some relative costs (based on the Colombia's official fee manual) ${ }^{1}$. On the other hand, in Honduras and Nicaragua we had reports of the cost of the reagents required for carrying out each test. Taking into account the lab production level, a cost for each test was estimated, adjusting the relative prices using Colombia's official fee manual. The cost estimation at the three scenarios was compared with the price of each test in a private provider. This initial estimation based on total cost at the lab was subestimating the true value of each test. For that reason, correction factors were estimated for each test, keeping their relative prices. This adjustment method allowed assigning more actual costs for each lab test in each country, which remained lower than those of the private market for each scenario.

Drug costs: Drug purchase prices in the institution were used based on the reports delivered by the procurement department. The drugs were purchased by the Ministry of Health's central administration, buying them for the entire public hospital network and delivering the same items to each hospital. Cost of drugs that were used but that did not appear in the purchase reports were not covered.

Costs of procedures: included oxygen masks, atomization, mechanical ventilation, blood transfusions, radiology exams, and others. The estimation was based on the determination of purchase prices of some supplies or the cost reports from local staff. As in the lab category, they were adjusted based on relative prices determined by Colombia's fee manual.

After the identification of the usage frequency by activity and their estimated unit cost, the cost per patient was estimated. All costs were estimated by patient in 2011 local currency (LCU), and converted to US dollars (USD), according to the local exchange rate of December 31 ${ }^{\text {st }}, 2011$ (7.64 for Guatemala, 18.54 for Honduras and 22.52 for Nicaragua), and international dollars using the exchange rates purchasing power parity adjusted for 2005 (4.12, 7.61 and 4.95, respectively), which even though they corresponded to a fictitious currency, give an idea of the difference in prices among each one of the countries. Figure 1 summarizes the methodological process followed by the estimated SARI costs.

Information analysis: Collected data were integrated to databases in MS Excel ${ }^{\mathrm{TM}}$ spreadsheets and Stata $11^{\mathrm{TM}}$. Statistical analyses were carried out using descriptive tools. In Stata $11^{\mathrm{TM}}$, an analysis algorithm was structured to estimate the cost parameters considered in the study. 


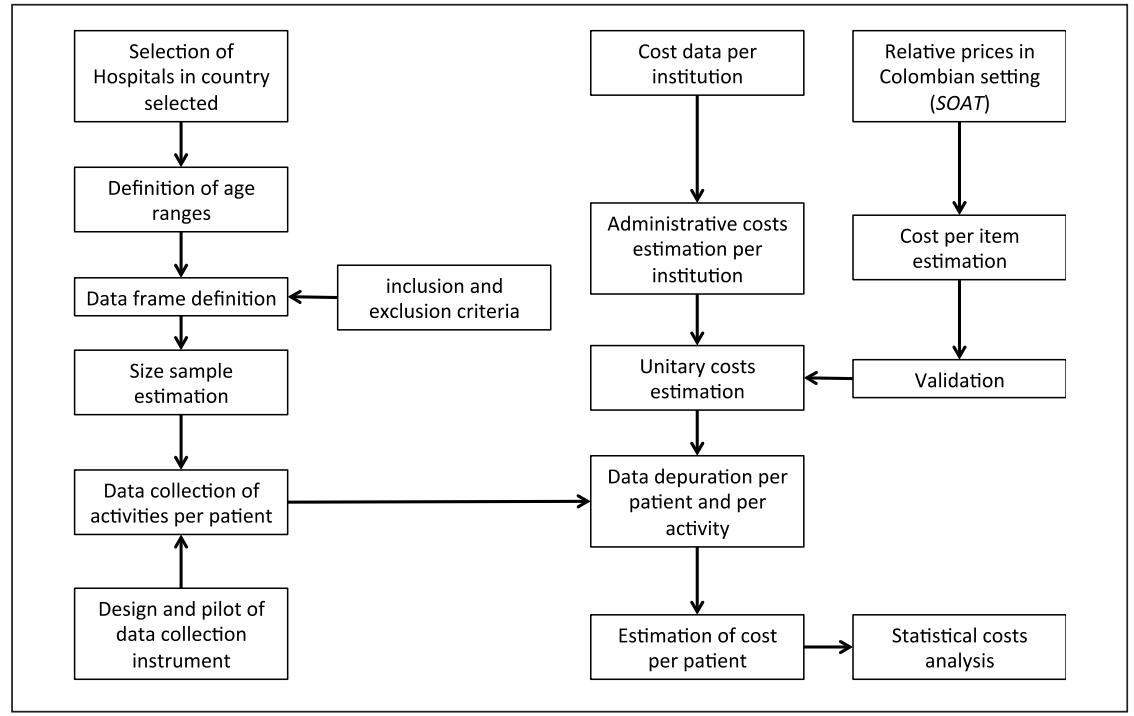

Figure 1. Flow chart for SARI costs estimation in three Central American countries

Source: Team of researchers of the Project Costs, 2011-2012

\section{Results}

A total of 567 medical records were reviewed. Table 1 shows the compliance of the number of reviewed records, lethality, gender, and age average. The total number of deaths that occurred in the sample was 19 cases, for a global lethality of 3.35\% (CI95\% 1.86-4.84). For children in Nicaragua there were no deaths. The fatality rate among countries was not statistically different ( $p>0.05)$, even though in the adult registries reviewed in Guatemala there were more deaths than in Honduras. The ages in the adult groups were similar in Guatemala and Honduras $(p=0.30)$. In children, their ages in Guatemala were different to Nicaragua and Honduras $(p<0.001)$.

Regarding hospitalization length, in the general ward the average stay for children, as well as adults, was different in all three countries $(p<0.001)$ (Table 2$)$. Hospitalizations were significantly longer in adults than in children $(p<0.001)$. Additionally, the length of hospitalization in the ICU was longer in children from Guatemala compared with Nicaragua $(p=0.05)$.

Included diagnoses: While in Guatemala most cases (>90\%) were classified as unclassified bacterial or viral pneumonia, in Honduras and Nicaragua, many cases referred to unidentified organism pneumonia. There was no diagnosis for influenza due to identified influenza virus or for pneumonia due to Haemophilus influenza, acute bronchitis, adult respiratory distress syndrome or unclassified respiratory insufficiency (Table 3).

The most important antecedent data in Guatemala was 25\% of children reported anemia, followed by malnutrition in $17 \%$, while in adults, arterial hypertension was present in $45 \%$, diabetes mellitus in $32 \%$, COPD in $25 \%$ and anemia and CHF in $8 \%$, each one. In Honduras, $31 \%$ of children had anemia and $25 \%$ malnutrition, while in adults, $18 \%$ had COPD and $12 \%$ had CHF. In Nicaragua, $24 \%$ of children had malnutrition and $10 \%$ had anemia.

\section{Cost analysis}

The cost per OBD for each institution was estimated without including medical staff costs, laboratories, procedures and/or drugs. We found that for pediatrics, general hospitalization was more expensive in Guatemala, and 5.5-fold less expensive in Honduras, using international dollars as a reference (I\$). For ICU costs, the relation was 2.7 times. In adults, general hospitalization was more expensive in Guatemala and more than 4.5 times less expensive in Honduras; for ICU, the relation was 3.7 times (Table 4).

In the group of children that only required general hospitalization, the average total cost in 2011USD, was higher in Honduras (US\$722.83), compared with Guatemala and Nicaragua (US\$ 524.84 and US\$314.88, respectively) (Table 5), due to the average number of hospitalization days in Honduras was higher. In addition, in Honduras only children under 3 years of age were included. However, the differences were not so big when the average cost was evaluated in international dollars.

In the adult group, in those who only required general hospitalization, there were significant differences $(p<0.05)$ between Guatemala and Honduras, in terms of average cost per patient in 2011 USD (US\$2,195.06 in Guatemala vs. 1,111.31 in Honduras), even though there was no difference in the length of stay. The average total cost per patient that required ICU, additional to the general hospitalization, when comparing the children's group in Guatemala and Nicaragua in 2011USD, was higher in Guatemala (US\$2,893.27 vs. 971.64). The difference also was less when it was adjusted by purchasing power parity.

The costs for the main diagnoses in pediatric patients are shown in Table 6 in international dollars. Cost for bronchiolitis is very similar to pneumonia by an unspecified organism 
Table 1. Main characteristics of patients with SARI diagnosis included in the analysis. Guatemala, Honduras and Nicaragua, $2009-2011$

\begin{tabular}{|c|c|c|c|c|c|c|}
\hline Hospital & Population & $\begin{array}{l}\text { N } \\
\text { (Fulfillment regarding } \\
\text { the needed sample \%) }\end{array}$ & $\begin{array}{l}\text { Average age } \\
\text { (Cl 95\%) }\end{array}$ & Age range & $\begin{array}{c}\text { Female } \\
(\%)\end{array}$ & $\begin{array}{c}\text { Lethality (Cl } \\
95 \%)\end{array}$ \\
\hline \multirow{2}{*}{$\begin{array}{l}\text { HGSJD } \\
\text { (Guatemala) }\end{array}$} & $\begin{array}{l}\text { Children } \\
\text { (months) }\end{array}$ & $\begin{array}{c}207 \\
(204.0)\end{array}$ & $\begin{array}{c}30.08 \\
(26.67-33.49)\end{array}$ & $6-108$ & 42.70 & $\begin{array}{c}2.4 \% \\
(0.3-4.5)\end{array}$ \\
\hline & Adults (years) & $\begin{array}{c}83 \\
(92.2)\end{array}$ & $\begin{array}{c}76.63 \\
(74.90-78.37)\end{array}$ & $64-95$ & 65.10 & $\begin{array}{c}12.0 \% \\
(4.9-19.2)\end{array}$ \\
\hline \multirow{2}{*}{$\begin{array}{l}\text { HMCR } \\
\text { (Honduras)* }\end{array}$} & $\begin{array}{l}\text { Children } \\
\text { (months) }\end{array}$ & $\begin{array}{c}109 \\
(112.4)\end{array}$ & $\begin{array}{c}17.34 \\
(16.07-18.61)\end{array}$ & $6-35$ & 45.00 & $\begin{array}{c}0.9 \% \\
(0-2.7)\end{array}$ \\
\hline & Adults (years) & $\begin{array}{c}56 \\
(101.8)\end{array}$ & $\begin{array}{c}74.09 \\
(71.62-76.56)\end{array}$ & $60-93$ & 17.90 & $\begin{array}{c}5.4 \% \\
(0-11.4)\end{array}$ \\
\hline $\begin{array}{l}\text { HIMJR } \\
\text { (Nicaragua) }\end{array}$ & $\begin{array}{l}\text { Children } \\
\text { (months) }\end{array}$ & $113(110.7)$ & $\begin{array}{c}24.51 \\
(21.13-27.88)\end{array}$ & $6-103$ & 35.40 & $0.0 \%$ \\
\hline
\end{tabular}

* Two cases of Honduras treated in ICU not sowed

Source: Team of researchers of the Project's Costs 2011-2012

and different to unclassified bacterial pneumonia. Regarding the patient that required ICU hospitalization, pneumonia by an unspecified organism had double the cost in Honduras than in Nicaragua. For Guatemala and Honduras, the cost for unclassified bacterial pneumonia was very similar, while unspecified organism pneumonia had a higher cost in Honduras. In adults, all diagnoses had a similar treatment cost.

\section{Discussion}

The present study shows the estimation of treatment costs per patient hospitalized due to SARI in three countries in Central America, from retrospective micro-costing (bottomup) analysis of a random sample with cases occurring between 2009 and 2011. According to our results for OBD costs, the more expensive setting for the two services considered was Guatemala (I\$148.72 general pediatric hospitalization,

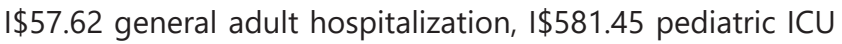
and $\$ \$ 474.30$ adult ICU), and the less expensive was Honduras ( $\$ 26.70$ for general pediatric or adult hospitalization, and I\$127.07 for ICU for any type of patient). These same differences among the costs for OBD were seen in the estima- tions held in Choosing Interventions that are Cost Effective (WHO-CHOICE) for these three countries, where the DCO costs in university hospital (as the included in this study), were $\mathbf{I} \$ 55.15$ in Guatemala, $\mathbf{\$} \$ 43.93$ in Honduras and $\mathbf{\$} \$ 27.78$ in Nicaragua (Table 7).

In terms of total cost in international dollars for pediatric care cases that only required general hospitalization, Guatemala was the least expensive country (I\$971.95) compared to $\mathrm{Ni}$ caragua $(\$ 1,431.96)$ and Honduras $(\$ 1,761.29)$. However, in adults, Guatemala was the country with the most expensive care: $\$ \$ 4,065.00$ vs. $\$ \$ 2,707.91$ in Honduras. In children requiring care in the ICU, the total cost per case was somewhat higher in Guatemala $(\mathbf{\$} 5,358.00)$ compared to Nicaragua (I\$4,418.67).

When the total average costs per patient were compared with the reported literature for pediatric patients for middleincome countries of treatment costs for hospitalized pneumonia (Table 8), there was great variability in the different estimates. The range in which the estimations fluctuated was between 2011 US\$849.5 and 5,547.8. However, in few stu-

Table 2. Length of stay in general hospitalization service and ICU for SARI patients. Guatemala, Honduras and Nicaragua, 2009-2011

\begin{tabular}{|c|c|c|c|c|c|c|}
\hline Hospital & Population & $\mathbf{n}$ & $\begin{array}{c}\text { Average length of } \\
\text { stay (days) }\end{array}$ & $\begin{array}{l}\text { Standard } \\
\text { deviation }\end{array}$ & Cl $95 \%$ & $\begin{array}{c}\text { Range of length } \\
\text { of stay (days) }\end{array}$ \\
\hline \multicolumn{7}{|c|}{ General hospitalization } \\
\hline \multirow{2}{*}{$\begin{array}{l}\text { HGSJD } \\
\text { (Guatemala) }\end{array}$} & Children & 196 & 5.96 & 0.355 & $5.26-6.66$ & $1-37$ \\
\hline & Adults & 83 & 12.60 & 0.852 & $10.92-14.29$ & $2-42$ \\
\hline \multirow{2}{*}{ HMCR (Honduras) } & Children & 108 & 7.21 & 0.378 & $6.47-7.95$ & $3-26$ \\
\hline & Adults & 55 & 11.40 & 1.186 & $9.06-13.74$ & $4-53$ \\
\hline HIMJR (Nicaragua) & Children & 99 & 5.76 & 0.254 & $5.26-6.25$ & $3-19$ \\
\hline \multicolumn{7}{|c|}{ ICU } \\
\hline $\begin{array}{l}\text { HGSJD } \\
\text { (Guatemala) }\end{array}$ & Children & 10 & 6.10 & 0.936 & $4.17-8.03$ & $2-10$ \\
\hline HIMJR (Nicaragua) & Children & 13 & 5.38 & 0.747 & $3.92-6.85$ & 13 \\
\hline
\end{tabular}

Source: Team of researchers of the Project's Costs 2011-2012 
Table 3. Diagnoses Included in patients with SARI. Guatemala, Honduras and Nicaragua, 2009-2011

\begin{tabular}{|c|c|c|c|c|c|c|}
\hline \multirow[b]{2}{*}{ Diagnoses } & \multicolumn{2}{|c|}{ Guatemala } & \multicolumn{2}{|c|}{ Honduras } & \multirow{2}{*}{$\begin{array}{c}\text { Nicaragua } \\
\text { Children } \\
\text { (\%) }\end{array}$} & \multirow{2}{*}{$\begin{array}{c}\text { Total } \\
(\%)\end{array}$} \\
\hline & $\begin{array}{l}\text { Children } \\
\text { (\%) }\end{array}$ & $\begin{array}{l}\text { Adults } \\
(\%)\end{array}$ & $\begin{array}{l}\text { Children } \\
\text { (\%) }\end{array}$ & $\begin{array}{c}\text { Adults } \\
(\%)\end{array}$ & & \\
\hline $\begin{array}{l}\text { Acute obstructive laryngitis (CROUP) and } \\
\text { epiglottitis }\end{array}$ & 0.97 & -- & -- & -- & -- & 0.35 \\
\hline Influenza virus due to unidentified agent & 0.97 & -- & -- & -- & -- & 0.35 \\
\hline $\begin{array}{l}\text { Viral pneumonia not classified elsewhere } \\
\text { (adenovirus, PI, RSV) }\end{array}$ & 21.36 & 4.82 & -- & -- & 0.89 & 8.66 \\
\hline $\begin{array}{l}\text { Pneumonia due to Streptococcus pneumoniae } \\
\text { (pneumococcus) }\end{array}$ & 0.00 & 3.61 & -- & -- & -- & 0.53 \\
\hline Bacterial pneumonia not classified elsewhere & 71.36 & 90.36 & -- & 21.43 & 8.04 & 42.93 \\
\hline Pneumonia, unspecified agent & 2.43 & 1.20 & 90.83 & 78.57 & 90.18 & 44.17 \\
\hline Acute bronchiolitis & 1.46 & -- & 9.17 & -- & 0.89 & 2.47 \\
\hline Unspecified acute lower respiratory tract & 0.97 & -- & -- & -- & -- & 0.35 \\
\hline No register & 0.49 & -- & -- & -- & -- & 0.18 \\
\hline
\end{tabular}

Source: Team of researchers of the Project's Costs 2011-2012

dies they consider a discriminate estimation for uncomplicated hospitalized pneumonia (equivalent to our pneumonia that only requires general hospitalization) and complicated hospitalized pneumonia (equivalent to our pneumonia that requires $\mathrm{ICU})$. In this study, we estimated in children an average value fluctuating between 2011 US $\$ 314.88$ and 722.83 , for pneumonia that only required general hospitalization and between 2011 US\$971.64 and 2,893.27 for pneumonia that required ICU. These values were greater than the estimations for the pediatric population in Latin America and the Caribbean, which were lower to those estimated for Colombia ${ }^{15}$ with a bottom-up costing exercise.

In the elderly population, there were few estimations of the treatment cost for pneumonia that had taken place in Latin America and the Caribbean. In a study carried out in Colombia, with the purpose of valuing the introduction of pneumococcal vaccine in elderly adults ${ }^{16}$, they estimated costs for pneumonia in hospitalized patients from the databases for individual health service registries (RIPS) (top-down costing). Adjusted by inflation at 2011, the exchange rate would be between 2011 U\$908.5 - 2011 U\$3,603.2, only a little higher than our findings, despite the fact that Colombia is a middleincome country.

In order to compare low-income countries (like those included in the present studio) and middle-income countries, the costs were adjusted to international dollars from 2011 and we established the proportion country/Nicaragua, to have an idea of how many times the costs were reproduced in each country in each hospital for an uncomplicated pneumonia, given that Nicaragua was the country with the lowest cost among all three participants in the study (Table 10). Based on this, we can see that Guatemala is close to double than Nicaragua, even though its GDP per capita is only 1.4 times higher. Regarding the comparison among middle-income countries, the cost to treat an uncomplicated pneumonia in a hospital in Chile, is eight times more expensive than in $\mathrm{Ni}$ caragua, while Chilean GDP per capita is only 5.8 times hig- her. On the other hand, the same relation between Brazil and Nicaragua is only 1.1 times, even though Brazil has 4 times more GDP per capita than Nicaragua.

Recent studies that estimated the cost for bronchiolitis showed that they could represent between 60 and $70 \%$ of the cost to treat an uncomplicated bacterial pneumonia ${ }^{20}$, very similar to the estimates in this study. Similarly, the length of stay due to bronchiolitis in this study was between 5.26 and 6.25 days in Nicaragua, similar to the reports in other studies ${ }^{21}$.

The value of this study is that it used a meticulous bottom-up costing technique for the included SARI cases, which allowed us to estimate the average cost per treated case, with their corresponding confidence intervals. The costs derived from this study, done from a hospital perspective, are a good estimator of the health system costs, because in these countries the population that does not have insurance is above $70 \%$ (22-24). It means that subsidies granted by the State are directly transferred to the hospitals, and hospital assistance costs are a referent for health care costs in the system.

Table 4. Costs per occupied bed/day (OBD) in international dollars (I\$), Guatemala, Honduras and Nicaragua, 2009-2011

\begin{tabular}{|c|c|c|c|c|}
\hline Setting & $\begin{array}{l}\text { Age } \\
\text { group }\end{array}$ & Guatemala & Honduras & Nicaragua \\
\hline \multirow{2}{*}{$\begin{array}{l}\text { General } \\
\text { hospitalization }\end{array}$} & Children & I\$ 148.72 & $1 \$ 26.70$ & $1 \$ 96.90$ \\
\hline & Adult & I\$ 57.62 & $1 \$ 20.70$ & NA \\
\hline \multirow[t]{2}{*}{ ICU } & Children & I\$ 581.45 & I\$ 127.07 & $1 \$ 206.88$ \\
\hline & Adult & $1 \$ 474.30$ & I\$ 127.07 & NA \\
\hline
\end{tabular}

* No difference was identified between pediatric and adult services, since costs could not be disaggregated specifically for care service.

+ This value was assumed according to the estimated in other countries, in terms of costs for day ICU/cost/hospitalization day. Only one patient required hospitalization in the ICU at one point.

Source: Team of researchers of the Project's Costs 2011-2012 
Table 5. Average cost per SARI patient. Guatemala, Honduras and Nicaragua, 2009-2012.

\begin{tabular}{|c|c|c|c|c|c|}
\hline Hospital & Population & $\mathbf{n}$ & $\begin{array}{l}\text { Average cost per patient } \\
\text { LCU } 2011\end{array}$ & $\begin{array}{c}\text { Average cost per patient } \\
\text { USD\$ } 2.011\end{array}$ & $\begin{array}{l}\text { Average cost per patient } \\
\text { I\$ } 2005\end{array}$ \\
\hline \multicolumn{6}{|c|}{ General hospitalization } \\
\hline \multirow{2}{*}{$\begin{array}{l}\text { HGSJD } \\
\text { Guatemala }\end{array}$} & Children & 196 & $\begin{array}{c}\$ 4,009.3 \\
(\$ 2,980.77-5,037.83)\end{array}$ & $\begin{array}{c}\text { USD } \$ 524.84 \\
\text { (USD\$ } 390.2-659.49)\end{array}$ & $\begin{array}{c}\text { I\$ } 971.95 \\
(I \$ 722.61-1,221.29)\end{array}$ \\
\hline & Adults & 83 & $\begin{array}{c}\$ 16,768.11 \\
(\$ 14,421.95-19,114.27)\end{array}$ & $\begin{array}{c}\text { USD\$ } 2195.06 \text { (USD\$ } \\
1887.93-2502.19)\end{array}$ & $\begin{array}{c}1 \$ 4,065 \\
(I \$ 3,496.23-4,633.76)\end{array}$ \\
\hline \multirow{2}{*}{ HMCR Honduras } & Children & 108 & $\begin{array}{c}\$ 13,403.43 \\
(\$ 11,614.9-15,191.95)\end{array}$ & $\begin{array}{c}\text { USD\$ } 722.83 \\
\text { (USD\$ } 626.37-819.28)\end{array}$ & $\begin{array}{c}\text { I\$ } 1,761.29 \\
(I \$ 1,526.27-1,996.31)\end{array}$ \\
\hline & Adults & 55 & $\begin{array}{c}\$ 20,607.2 \\
(\$ 16,056.82-25,157.59)\end{array}$ & $\begin{array}{c}\text { USD\$ } 1,111.31 \\
\text { (USD\$ } 865.92-1356.71)\end{array}$ & $\begin{array}{c}\mid \$ 2,707.91 \\
(I \$ 2,109.96-3,305.86)\end{array}$ \\
\hline $\begin{array}{l}\text { HIMJR } \\
\text { Nicaragua }\end{array}$ & Children & 99 & $\begin{array}{c}\$ 7,091.07 \\
(\$ 6,307.22-7,874.93)\end{array}$ & $\begin{array}{c}\text { USD\$ } 314.88 \\
\text { (USD\$ } 280.07-349.69)\end{array}$ & $\begin{array}{c}\text { I\$ } 1,431.96 \\
(I \$ 1,273.67-1,590.25)\end{array}$ \\
\hline \multicolumn{6}{|c|}{ General hospitalization + ICU } \\
\hline $\begin{array}{l}\text { HGSJD } \\
\text { Guatemala }\end{array}$ & Children & 10 & $\begin{array}{c}\$ 22,101.75 \\
(\$ 15,941.12-28,262.39)\end{array}$ & $\begin{array}{c}\text { USD\$ 2,893.27 (USD\$ } \\
2,086.8-3,699.74)\end{array}$ & $\begin{array}{c}\text { I\$5,358 (I\$ } 3864.51- \\
6851.49)\end{array}$ \\
\hline \multirow{2}{*}{$\begin{array}{l}\text { HMCR } \\
\text { (Honduras) }\end{array}$} & Children & 1 & $\$ 92,724$ & USD\$ 5,000 & I\$ $12,184.46$ \\
\hline & Adults & 1 & $\$ 264,393$ & USD\$ 14,258 & $1 \$ 34,742.84$ \\
\hline $\begin{array}{l}\text { HIMJR } \\
\text { (Nicaragua) }\end{array}$ & Children & 13 & $\begin{array}{c}\$ 21,881.27 \\
(\$ 14761.18-29001.36)\end{array}$ & $\begin{array}{c}\text { USD\$ } 971.64 \\
\text { (USD\$ } 655.47-1,287.8)\end{array}$ & $\begin{array}{c}1 \$ 4,418.67 \\
(I \$ 2,980.85-5,856.49)\end{array}$ \\
\hline
\end{tabular}

Source: Team of researchers of the Project's Costs 2011-2012

Table 6. Average cost per diagnosis code in children and adults in Guatemala, Honduras and Nicaragua (international dollars, 2005)

\begin{tabular}{|c|c|c|c|}
\hline Diagnoses, ICD 10 & Guatemala & Honduras & Nicaragua \\
\hline \multicolumn{4}{|l|}{$\begin{array}{l}\text { Children only in general } \\
\text { hospitalization }\end{array}$} \\
\hline Unclassified viral pneumonia & I\$559 & ND & I\$941 \\
\hline $\begin{array}{l}\text { Unclassified bacterial } \\
\text { pneumonia }\end{array}$ & $1 \$ 1,152$ & ND & I\$ 1,697 \\
\hline $\begin{array}{l}\text { Pneumonia, unspecified } \\
\text { organism }\end{array}$ & $1 \$ 655$ & I\$ 1,776 & I\$ 1,408 \\
\hline Acute bronchiolitis & $1 \$ 630$ & I\$ 1,614 & $1 \$ 1,392$ \\
\hline \multicolumn{4}{|l|}{$\begin{array}{l}\text { Children with UCI } \\
\text { hospitalization }\end{array}$} \\
\hline $\begin{array}{l}\text { Unclassified bacterial } \\
\text { pneumonia }\end{array}$ & $1 \$ 22,102$ & & \\
\hline $\begin{array}{l}\text { Pneumonia, unspecified } \\
\text { organism }\end{array}$ & & I\$ 12,184 & II\$ 4,419 \\
\hline \multicolumn{4}{|l|}{$\begin{array}{l}\text { Adults only in general } \\
\text { hospitalization }\end{array}$} \\
\hline Unclassified viral pneumonia & I\$ 17,279 & & \\
\hline $\begin{array}{l}\text { Pneumonia due to } \\
\text { Streptococcus pneumoniae }\end{array}$ & I\$ 16,080 & & \\
\hline $\begin{array}{l}\text { Unclassified bacterial } \\
\text { pneumonia }\end{array}$ & I\$ 16,801 & $1 \$ 17,383$ & \\
\hline $\begin{array}{l}\text { Pneumonia, unspecified } \\
\text { organism }\end{array}$ & I\$ 14,346 & $1 \$ 21,507$ & \\
\hline
\end{tabular}

Source: Team of researchers of the Project's Costs 2011-2012
Table 7. Report for CHOICE data for the included countries of the cost of bed/day spending in international dollars (I\$), according to complexity level, 2008

\begin{tabular}{|l|c|c|c|}
\hline \multicolumn{1}{|c|}{ Setting } & Guatemala & Honduras & Nicaragua \\
\hline $\begin{array}{l}\text { Hospital first } \\
\text { level }\end{array}$ & $1 \$ 40.88$ & $\$ 32.57$ & $1 \$ 20.59$ \\
\hline $\begin{array}{l}\text { Hospital } \\
\text { Second level }\end{array}$ & $\$ 42.65$ & $\$ 33.98$ & $1 \$ 21.48$ \\
\hline $\begin{array}{l}\text { University } \\
\text { hospital }\end{array}$ & $\$ \$ 55.15$ & $\$ 43.93$ & $1 \$ 27.78$ \\
\hline
\end{tabular}

Source: Report from the CHOICE tool

This study has limitations. The main is related to the lack of completeness in the information registered in the clinical records. Additionally, it lacks information to triangulate from standardized databases, to validate values of supplies and laboratories, among others. We had obstacles in collecting information in a unified and systematic manner at the hospital's departments and the own limitations of the retrospective costing studies.

\section{Ethical disclosures}

Protection of human and animal subjects. This research do not used human nor animal material.

Confidentiality of data. The authors declare that no patient data appears in this article.

Right to privacy and informed consent. The authors declare that no data that enables identification of the patients appears in this article. 
Table 8. Hospital care treatment costs for uncomplicated pneumonia in medium- and low income-countries for LAC

\begin{tabular}{|c|c|c|c|c|c|}
\hline Author & Country and year & Costs (USD\$2011) & Cost (I\$ 2011) & $\begin{array}{c}\text { Ratio pneumonia } \\
\text { cost country } \\
\text { Nicaragua }\end{array}$ & $\begin{array}{c}\text { Ratio GDPpc country/ } \\
\text { GDPpc Nicaragua (I\$ } \\
\text { 2011) }\end{array}$ \\
\hline \multirow{3}{*}{ Constenla, et al. (17) } & \multirow{3}{*}{$\begin{array}{l}\text { Brazil, Chile, Uruguay } \\
2008 \text { (USD\$ 2004) }\end{array}$} & Brazil, hospitalized: 849.5 & I\$790.01 & 1.1 & 4.0 \\
\hline & & Chile, hospitalized: $4,867.2$ & $1 \$ 5,790.42$ & 7.8 & 5.8 \\
\hline & & $\begin{array}{l}\text { Uruguay, hospitalized: } \\
\qquad 2,201.8\end{array}$ & $1 \$ 2,212.66$ & 3.0 & 5.2 \\
\hline Urueña, et al. (18) & $\begin{array}{l}\text { Argentina } \\
2011 \text { (USD\$2009) }\end{array}$ & $\begin{array}{c}\text { Public sector, } \\
\text { Hospitalized: 1,133 }\end{array}$ & I\$ $1,830.24$ & 2.5 & 6.0 \\
\hline Castañeda, et al. (19) & $\begin{array}{l}\text { Colombia } \\
2011 \text { (USD\$2011) }\end{array}$ & Hospitalized: 1,649.9 & $1 \$ 2,357.41$ & 3.2 & 3.4 \\
\hline \multirow{3}{*}{ Current study (2012) } & Guatemala & Hospitalized: 524.8 & I\$ $1,320.3$ & 1.8 & 1.4 \\
\hline & Honduras & Hospitalized: 722.8 & I\$ 819.2 & 1.1 & 1.7 \\
\hline & Nicaragua & Hospitalized: 314,9 & $1 \$ 742.94$ & 1.0 & 1.0 \\
\hline
\end{tabular}

Source: Team of researchers of the Project's Costs 2011-2012

Funding. None declared

\section{Conflicts of interest. None declared}

\section{References}

1. Cashat-Cruz M, Morales-Aguirre JJ, Mendoza-Azpiri M. Respiratory tract infections in children in developing countries. Semin Pediatr Infect Dis. 2005;16(2):84-92. Epub 2005/04/13.

2. Nair H, Simoes EA, Rudan I, Gessner BD, Azziz-Baumgartner E, Zhang $J \mathrm{~S}$, et al. Global and regional burden of hospital admissions for severe acute lower respiratory infections in young children in 2010: a systematic analysis. Lancet. 2013;381(9875):1380-90. Epub 2013/02/02.

3. Leowski J. Mortality from acute respiratory infections in children under 5 years of age: global estimates. World Health Stat Q. 1986;39(2):138-44. Epub 1986/01/01.

4. Abarca VK. Influenza: vacunación a nuevos grupos etarios. Rev Chilena Infectol. 2007:24(3):227-30.

5. Monto AS. Global burden of influenza: what we know and what we need to know. Int Congr Ser. 2004;1263:3-11.

6. Shek LP, Lee BW. Epidemiology and seasonality of respiratory tract virus infections in the tropics. Paediatr Respir Rev. 2003;4(2):105-11. Epub 2003/05/22.

7. Brooks WA, Alamgir AS, Sultana R, Islam MS, Rahman M, Fry AM, et al. Avian influenza virus $A(H 5 N 1)$, detected through routine surveillance, in child, Bangladesh. Emerg Infect Dis. 2009;15(8):1311-3. Epub 2009/09/16.

8. Zaman RU, Alamgir AS, Rahman M, Azziz-Baumgartner E, Gurley ES, Sharker MA, et al. Influenza in outpatient ILI case-patients in national hospital-based surveillance, Bangladesh, 2007-2008. PLoS One. 2009;4(12):e8452. Epub 2009/12/31.

9. Gordon A, Ortega O, Kuan G, Reingold A, Saborio S, Balmaseda A, et al. Prevalence and seasonality of influenza-like illness in children, Nicaragua, 2005-2007. Emerg Infect Dis. 2009;15(3):408-14. Epub 2009/02/26.

10. Lindblade KA, Arvelo W, Gray J, Estevez A, Frenkel G, Reyes L, et al. A comparison of the epidemiology and clinical presentation of seasonal influenza A and 2009 pandemic influenza A (H1N1) in Guatemala. PLoS One. 2010;5(12):e15826. Epub 2011/01/07.

11. Reyes L, Arvelo W, Estevez A, Gray J, Moir JC, Gordillo B, et al. Populationbased surveillance for 2009 pandemic influenza A (H1N1) virus in Guatemala, 2009. Influenza Other Respir Viruses. 2010;4(3):129-40. Epub 2010/04/23.

12. Molinari NA, Ortega-Sanchez IR, Messonnier ML, Thompson WW, Wortley PM, Weintraub $E$, et al. The annual impact of seasonal influenza in the US: measuring disease burden and costs. Vaccine. 2007;25(27):5086-96. Epub 2007/06/05.
13. Keech $M$, Beardsworth P. The impact of influenza on working days lost: a review of the literature. Pharmacoeconomics. 2008;26(11):911-24. Epub 2008/10/15.

14. Giachetto Larraz G, Telechea Ortiz H, Speranza Mourine N, Giglio N Cane A, Pirez Garcia MC, et al. Costo-efectividad de la vacunación universal antineumocócica en Uruguay. [Cost-effectiveness of universal pneumococcal vaccination in Uruguay]. Rev Panam Salud Pública. 2010;28(2):92-9. Epub 2010/10/22.

15. Alvis-Guzman N, Orozco-Africano J, Paternina-Caicedo A, CoronellRodriguez W, Alvis-Estrada L, Jervis-Jalabe $\mathrm{D}$, et al. Treatment costs of diarrheal disease and all-cause pneumonia among children under- 5 years of age in Colombia. Vaccine. 2013;31(Suppl. 3):C58-62. Epub 2013/06/29.

16. Castaneda-Orjuela C, Alvis-Guzman N, Paternina AJ, De la HozRestrepo F. Cost-effectiveness of the introduction of the pneumococcal polysaccharide vaccine in elderly Colombian population. Vaccine. 2011;29(44):7644-50. Epub 2011/08/23.

17. Constenla DO. Economic impact of pneumococcal conjugate vaccination in Brazil, Chile, and Uruguay. Rev Panam Salud Pública. 2008;24(2):101-12. Epub 2008/12/10.

18. Uruena A, Pippo T, Betelu MS, Virgilio F, Giglio N, Gentile A, et al. Costeffectiveness analysis of the 10- a nd 13-valent pneumococcal conjugate vaccines in Argentina. Vaccine. 2011;29(31):4963-72. Epub 2011/05/31.

19. Castañeda-Orjuela C, Alvis-Guzman N, Velandia-Gonzalez M, De la HozRestrepo F. Cost-effectiveness of pneumococcal conjugate vaccines of 7 , 10, and 13 valences in Colombian children. Vaccine. 2012;30(11):1936-43. Epub 2012/01/24.

20. Rodriguez Martinez CE, Sossa Briceno MP. Costo-efectividad de la radiografía de tórax en lactantes con sospecha clínica de bronquiolitis viral en Colombia. [Cost-effectiveness of chest $\mathrm{x}$-rays in infants with clinically suspected viral bronchiolitis in Colombia]. Rev Panam Salud Pública. 2011;29(3):153-61. Epub 2011/04/13.

21. Diez Domingo J, Ridao Lopez M, Ubeda Sansano I, Ballester Sanz A. Incidencia y costes de la hospitalizacion por bronquiolitis y de las infecciones por virus respiratorio sincitial en la Comunidad Valenciana. Años 2001 y 2002. [Incidence and cost of hospitalizations for bronchiolitis and respiratory syncytial virus infections in the autonomous community of Valencia in Spain (2001 and 2002)]. An Pediatr (Barc). 2006;65(4):325-30. Epub 2006/10/06.

22. Becerril-Montekio V, Lopez-Davila L. Sistema de salud de Guatemala. [The health system of Guatemala]. Salud Pública Mex. 2011;53(Suppl.2):s197-208. Epub 2011/09/09.

23. Bermudez-Madriz JL, Saenz Mdel R, Muiser J, Acosta M. Sistema de salud de Honduras. [The health system of Honduras]. Salud Pública Mex. 2011;53(Suppl.2):s209-19. Epub 2011/09/09.

24. Muiser J, Saenz Mdel R, Bermudez JL. Sistema de salud de Nicaragua. [The health system of Nicaragua]. Salud Publica Mex. 2011;53(Suppl.2):s233-42. Epub 2011/09/09. 